\title{
Antioxidative and Antimicrobial Activities of Methanol Extract from Rosmarinus officinalis L. and Their Fractions
}

\author{
Mi Hee Yu', In Gyeong Chae ${ }^{1}$, Young Tae Jung ${ }^{1}$, Yeon Seop Jeong ${ }^{1}$, Hyuk II Kim ${ }^{1}$ and In Seon Lee ${ }^{1,2} \star$ \\ ${ }^{1}$ Department of Food Science and Technology, Keimyung University, Daegu 704-701, Korea \\ ${ }^{2}$ The Center for Traditional Microorganism Resources, Keimyung University, Daegu 704-701, Korea
}

Received November 9, 2010 /Accepted December 27, 2010

\begin{abstract}
This study was performed to evaluate the antioxidant and antimicrobial activity of methanol extract from Rosmarinus officinalis $\mathrm{L}$. and its fractions. The ethyl acetate fraction of rosemary had a higher antioxidant activity in both DPPH $(3.22 \mu \mathrm{g} / \mathrm{ml})$ and ABTS $(5.05 \mu \mathrm{g} / \mathrm{ml})$ compared to other extracts and fractions. Based on the results of the FRAP assay, the ethyl acetate fraction of rosemary showed a value of $5.9 \pm 0.3 \mu \mathrm{M} / \mu \mathrm{g}$, and buthanol fraction and rosmarinic acid exhibited values of $4.8 \pm 0.2 \mu \mathrm{M} / \mu \mathrm{g}$ and $5.1 \pm 0.1 \mu \mathrm{M} / \mu \mathrm{M}$, respectively. Measurements of the antimicrobial activities of the extracts, fraction against gram positive, negative bacteria revealed that the methanol extract, hexane, ethyl acetate, and chloroform fraction of rosemary caused Staphylococcus aureus and Escherichia coli to form clear zones greater than $12 \mathrm{~mm}$. Furthermore, the methanol extract and chloroform fraction showed high antibacterial activity, with inhibition zone exceeding $13 \mathrm{~mm}$. The methanol extract and chloroform fraction of rosemary had broad antimicrobial spectrums and low MIC values. Therefore, methanol extracts of rosemary could serve as potential antibacterial agents to inhibit pathogen growth in food and hand sanitizers.
\end{abstract}

Key words : Antimicrobial, antioxidative, rosemary, rosmarinic acid

\section{서 론}

최근 들어 인간의 수명이 증가하고 건강에 대한 관심이 높 아짐에 따라 여러 측면에서 노화억제와 건강유지를 위한 기능 성 생리활성 물질에 대한 연구가 미생물과 식물분야에서 광범 위 하게 연구되고 있다[14,37]. 생체 내에서 산화와 관련된 현 상으로 인식되고 있는 노화의 원인으로 산소에서 유래되는 superoxide, nitric oxide, hydroxyl, peroxyl, alkoxyl, hydroperoxyl radical 등과 같은 활성산소종(Reactive oxyzen species)은 미토콘드리아와 같은 세포 내 기관의 정상적인 대사 및 세포질 내 일부 효소들에 의하여 자연적으로 생성 되며, 세포 내에 적당량이 존재할 경우 여러 가지 세포반응을 조절 할 수 있는 신호분자가 된다[41]. 하지만 과량의 활성산소종은 DNA 분절과 단백질의 불활성화 및 세포 생체막의 구성성분 인 불포화 지방산을 공격하여 생체기능을 저하시킴으로써 노 화를 유발 할 뿐만 아니라 류마티스성 관절염, 당뇨병, 심장병, 동맥경화, 암 등과 같은 여러 질환의 원인으로 잘 알려져 있다 [41]. 생체 내에서는 superoxide dismutase (SOD), catalase, glutathione reductase 등의 항산화 효소와 tocopherol 등과 같은 천연항산화제가 존재하여 산소 상해에 대한 방어기능을 하고 있지만[8,22], 과도한 스트레스에 노출되어 있는 현대인 의 복잡한 생활 속에서 더욱 효과적인 식이성 항산화제의 필

*Corresponding author

Tel : +82-53-580-5538, Fax : +82-53-580-5538

E-mail : inseon@kmu.ac.kr
요가 절실해지고 있다. BHT (butylated hydroxytoluene), BHA (butylated hydroxyanisole), PG (proply gallate), TVHQ (tertiary butyihydroquinone), ascorbic acid, tocopherol류, $\beta$ -carotene 등은 활성산소의 산화기작을 여러 경로에서 차단하 거나 지연시키는 작용을 하는 항산화제로서 그 중 항산화 효 과가 뛰어난 BHT와 BHA의 합성항산화제는 우수한 효과와 저렴한 가격 때문에 tocopherol이나 vitamin $\mathrm{C}$ 보다 널리 사용 되고 있다. 그러나 $50 \mathrm{mg} / \mathrm{kg} / \mathrm{day}$ 의 용량에서 지질변화 및 발암 독성 때문에 사용이 제한되어[5,18], 인체에 부작용이 없 는 천연식물 추출물이 간접적으로 생체 내 항산화 방어시스템 을 증가시키거나 직접적으로 ROS를 소거시키는 효과가 있다 면 그 추출물은 다양한 질병을 예방하기 위한 기능성 소재로 사용될 수 있을 것이다[21].

또한 전 세계적으로 합성 식품첨가물에 대한 안전성과 사용 규정들이 다시 검토되면서 최근 천연 식품첨가물에 대한 관심 이 새롭게 대두되고 있다. 합성 항산화제의 독성에 대한 연구 는 오래 전부터 진행되어 왔으며, 'Food Chemical News' (1976)에 폐나 위장관 점막 같은 조직과 간에 미치는 $\mathrm{BHT}$ 의 유해성이 $\mathrm{FDA}$ 에 의해 보고된 바 있다. 최근에는 소비자의 건 강 지향적 옥구에 따라 식품첨가물에 대한 관심이 높아 화학 합성 보존제에 대한 기피현상이 강하게 나타나고 있어[13,23], 인체에 무해한 천연물 유래 항균제의 개발이 절실히 요구 되 고 있다. 이에 대응하여 식용식물 및 생약 등의 천연물로부터 특정성분을 추출하여 천연 식품 보존제를 개발하려는 연구가 활발히 진행되고 있고, 특히, 천연물이 가지는 2 차 대사산물인 
생리활성물질에 대한 관심이 증대되고 있다. 생리활성을 나타 내는 물질 중에 식품의 부패와 변질을 유발하는 미생물에 대 하여 항균활성을 나타내는 물질은 alkaloid, terpenoid, phenol 및 정유 성분과 같은 2 차 대사산물이거나 그 유도체들로 알려 져 있다[1,7,11,12,32,36,40,42,43]. 한편 전 세계적으로 널리 사 용되고 있는 천연 향신료들은 식품의 관능성 증대는 물론, 병 원성 세균 및 식품부패균에 대한 천연보존료로 사용 가능하며 $[4,25,45]$ 식물로부터 유래되는 휘발성 이차 대사산물인 정유 성분들은 항염증, 항알러지, 항암활성을 가지고 있으며 $[6,29,39]$ 이러한 정유는 수세기 동안 천연의 항균 복합제나 단일물질로서 이용되고 있고, 식중독균과 식품부패 미생물의 생장을 조절하는 목적으로 천연 식품보존제로서 정유의 사용 이 연구 개발되고 있다[30].

로즈마리(Rosmarinus Officinalis L.)는 지중해 연안이 원산 인 상록관목으로 소나무 잎처럼 뾰족한 잎에 장뇌와 비슷한 산뜻하고 강한 향이 나는 허브이다. 로즈마리는 예부터 향수, 약으로 사용되어 왔으며 역한 냄새를 제거하는 소취제의 역 할, 상큼한 향을 내는 부향제 역할, 살균작용과 항균작용 및 항산화 기능 등이 있어 식품의 보존성을 높이는 것으로 알려 져 있다[16]. 로즈마리의 주요 성분 및 정유 성분으로는 a -pinene, apigenin, $\beta$-carotene, $\beta$-sitosterol, betulinic acid, borneol, rosmanol, rosmarinic acid, 1-8 cineol, carnosol, carnosic acid, tannin, limonene, camphor, camphene, 칼슘, 철, 마그네슘, 망간, 인, 칼륨, 아연, 비타민 B1, B3, C 등이 있다[15].

이에 본 연구에서는 로즈마리로부터 메탄올 추출물 및 순차 적 용매 분획물과 단일성분을 얻은 후 이 식물이 가진 항산화 성 및 항균효과를 검색함으로써 로즈마리의 생리활성 효과와 식품 보존제 및 천연항균제등의 기능성 소재로서의 개발 가능 성을 알아보고자 하였다.

\section{재료 및 방법}

\section{시료 제조}

본 실험에 사용한 로즈마리는 대구시 약령시장에서 건조 상태의 것을 구입하여 사용하였다. 시료는 불순물 제거를 위 하여 수세한 후 건조하여 사용하였고, 무게의 10 배량 $(\mathrm{w} / \mathrm{v})$ 의 $80 \%$ 메탄올을 가하여 24 시간 동안 정치하여 총 3 회 반복 추출 하였다. 추출액은 여과지(Whatman No. 3, Whatman International Ltd., Maidstone, England)로 여과한 다음 rotary evaporator (UT-1000, EYELA, Tokyo, Japan)로 $55^{\circ} \mathrm{C}$ 에서 농 축한 후 동결 건조하여 메탄올 추출물로 사용하였다. 동결 건 조한 로즈마리 메탄올 추출물은 20 배 $(\mathrm{w} / \mathrm{v})$ 의 증류수에 녹인 후 hexane (hexane), chloroform $\left(\mathrm{CHCl}_{3}\right)$, ethylacetate (EtOAc) 및 butanol $(\mathrm{BuOH})$ 로 순차적으로 3회 반복 추출하여 각 용매별로 계통적으로 분획을 하였고 남은 수용성 층은 water 분획으로 감압농축 하여 speed vacuum으로 남은 유기용
매를 휘발시킨 뒤 $-20^{\circ} \mathrm{C}$ 에서 보관하면서 사용하였다. 또한 로 즈마리의 단일 물질은 a-pinene, rosmarinic acid, cineol, carnosol, carnosic acid, limonene, camphor, camphene을 Sigma (St. Louis, MO, USA)에서 구입하여 사용하였다.

\section{$a$ - $a$-Diphenyl- $\beta$-picrylhydrazyl (DPPH) radical 소거 활성}

시료의 free radical 소거 활성은 stable radical인 $a-a$ -diphenyl- $\beta$-picrylhydrazyl (DPPH)에 대한 환원력을 측정한 것으로 $99 \%$ 메탄올에 각 시료를 녹여 농도별로 희석한 희석액 $160 \mu 1$ 와 메탄올에 녹인 $0.15 \mathrm{mM} \mathrm{DPPH}$ 용액 $40 \mu 1$ 를 가하여 실온에 30분 방치한 후 $517 \mathrm{~nm}$ 에서 흡광도를 측정하였다. 각 시료 추출물의 유리라디칼 소거활성은 시료를 첨가하지 않은 대조구의 흡광도를 $1 / 2$ 로 환원시키는데 필요한 시료의 농도 인 $\mathrm{RC}_{50}$ 값으로 나타내었다. 이때 활성비교를 위하여 $\mathrm{BHA}$ 와 ascorbic acid를 사용하였다.

\section{Ferric reducing/antioxidant power (FRAP) 측정}

FRAP assay는 Benizie와 Strain 방법[3]을 96 well plate에 맞게 수정하여 실시하였다. 반응액은 $300 \mathrm{mM}$ acetate buffer (pH 3.6) : 10 mM TPTZ (2,4,6-tripyridyl-s-triazine) : $20 \mathrm{mM}$ $\mathrm{FeCl}_{3} \cdot 6 \mathrm{H}_{2} \mathrm{O}$ 를 $10: 1: 1$ 의 비율로 실험 직전에 만들어 사용하였 다. 반응액과 시료를 혼합하여 4분간 반응시킨 후 $593 \mathrm{~nm}$ 에서 흡광도를 측정하였다. 시료의 환원력은 $0.1 \sim 1 \mathrm{mM} \mathrm{FeSO}_{4}$ $7 \mathrm{H}_{2} \mathrm{O}$ 로 표준곡선을 작성하여 추출물 $1 \mu \mathrm{g}$ 당 $\mathrm{Fe}^{2+} \mu \mathrm{mole}$ 로 표시하였다.

\section{ABTS radical 소거 활성}

7 mM 2,2'-azino-bis (3-ethylbenzthiazoline-6-sulfonic acid) (ABTS, Sigma Chemical Co., St. Louis, MO, USA)와 $2.45 \mathrm{mM}$ potassium persulfate를 최종 농도로 혼합하여 실온 인 암소에서 24시간 동안 방치하여 $\mathrm{ABTS}+$-을 형성시킨 후 96 well에 $734 \mathrm{~nm}$ 에서 흡광도 값이 0.70 $( \pm 0.02)$ 이 되게 phos $^{-}$ phate buffer saline (PBS, $\mathrm{pH}=4$ )로 희석하였다. 희석된 용액 $180 \mu 1$ 에 sample $20 \mu 1$ 를 가하여 정확히 1 분 동안 방치한 후 흡광도를 측정하였다. 각 시료 추출물과 단일 물질의 유리 라 디칼 소거 활성은 시료를 첨가하지 않은 대조구의 흡광도를 $1 / 2$ 로 환원시키는데 필요한 시료의 농도인 $\mathrm{RC}_{50}$ 값으로 나타 내었다.

\section{사용 균주 및 배지}

본 실험에서 사용한 Escherichia coli $\mathrm{O} 157: \mathrm{H} 7$ 의 표준균주인 ATCC 43888는 미국균주보존센터로부터, Staphylococcus aureus의 표준균주인 KCTC 1621 는 한국생명공학연구원 생물자 원센터로 분양 받아 각각의 균들을 tryptic soy broth (TSB, $\mathrm{Difco}$, Detroit, USA)에 1 백금이 접종하여 $37^{\circ} \mathrm{C}$ 에서 24 시간 
shaking 하여 3회 계대 배양 후 성장 최적조건에서 배양 시켰 다. 또한, 생균수 측정을 위한 배지는 tryptic soy broth agar (TSA, Difco)를, 세균을 희석하기 위한 희석수로는 멸균 증류 수를 사용하였다.

\section{항균활성 측정}

추출물의 항균력 검색은 disc diffusion method[24]법을 실 시하였다. 균주를 $100 \mathrm{ml} \mathrm{TSB}$ 에 접종하고 $37^{\circ} \mathrm{C}$ 에서 shaking하 면서 24시간 배양하여 활성화시키고 3일 계대 배양 후 $\mathrm{spec}^{-}$ trophotometer (UNIKON922, Kontron, Milan, Italy)를 이용 하여 $560 \mathrm{~nm}$ 에서 O.D값이 0.2 가 되게 하여 균수를 $1 \times 10^{7}$ $\mathrm{cfu} / \mathrm{ml}$ 로 사용하였다. 고체배지에 멸균된 glass spreader로 균 을 고르게 spread 한 후, $8 \mathrm{~mm}$ paper disc (diamerter $8 \mathrm{~mm}$, Adantec co., Tokyo, Japan)를 올려놓은 다음 추출물을 최종농 도가 $2.5,5 \mathrm{mg} / \mathrm{disc}$ 가 되도록 $\mathrm{DMSO}$ 에 용해시키고 $50 \mu \mathrm{l}$ 를 주입하여 완전히 흡수시킨 후 $37^{\circ} \mathrm{C}$ incubator에서 24 시간 배 양시켜 paper disc 주위의 inhibition zone $(\mathrm{mm})$ 의 직경을 측 정하였다.

최소저해농도 측정(Minimum Inhibitory Concentration)

시료 추출물에 대한 최소저해농도(Minimum Inhibitory Concentration, MIC) 분석은 broth-dilution method[28]를 사 용하여 수행하였다. 추출물을 DMSO에 $1 \sim 10 \mathrm{mg} / \mathrm{ml}$ 의 농도 로 희석하였다. 각각의 균주는 농도를 O.D. $560=0.2$ 로 조절한 후 본 실험에 사용하였다. 96 well plate에 균 희석액 $180 \mu \mathrm{l}$, 시료 추출물의 조제액 $20 \mu 1$ 를 농도별로 첨가한 뒤 24시간 동안 $37^{\circ} \mathrm{C}$ 에서 배양하였다. 균의 생육 곡선 상에서 균의 생 장(turbidity)이 검출되지 않는 최소 농도를 $\mathrm{MIC}$ 로 설정 하 였다.

\section{손 세정 효과}

추출물에 대한 항균력 응용은 Hand Plate (Komed Co Ltd., SeongNam-City, Korea)를 이용하였다. 로즈마리 $\mathrm{MeOH}$ 추출 물 1, 5\% 농도의 희석액 $1 \mathrm{ml}$ 과 대조군 3 차 멸균 증류수 1 $\mathrm{ml}$ 을 각각 손에 바른 후 Hand Plate 표면에 가볍게 접촉시켜 3-5초 경과 뒤 손을 땐 다음 $37^{\circ} \mathrm{C}$ incubator에서 24 시간 배양 후 세균의 집락의 색깔과 수를 관찰하였다.

식품의 저장성 연장

시료 추출물에 대한 우유의 신선도 측정은 시간적 소요를 줄여 주는 Resazurin 환원시험[35]을 사용하였다. 시료유 10 $\mathrm{ml}$ 를 멸균공전시험관에 취하고 Resazurin 용액 $1 \mathrm{ml}$ 를 가한 후 마개를 잘 막은 뒤 조용히 3회 전도 혼합하고, 즉시 차광한 $37^{\circ} \mathrm{C}$ 의 항온조에 넣어 30 분간 방치 하였다. 방치 후 시험관을 꺼내어 3 회 정도 전도 혼합하고 다시 항온조에 넣어서 $37^{\circ} \mathrm{C}$ 로 30 분간 유지 한 다음(배양시작 후 60 분), 시험관을 꺼내어 아래 로부터 $4 / 5$ 의 색깔을 직사일광을 피해서 표준색표와 비교하 였다.

\section{결과 및 고찰}

\section{DPPH free radical 소거활성}

$\mathrm{DPPH}$ 는 화학적으로 안정화된 free radical을 가지고 있는 수용성 물질로 ascorbic acid, tocopherol, polyhydroxy 방향족 화합물 등에 의해 환원되어 짙은 자색이 탈색되는데, 이것은 다양한 천연 소재로부터 항산화물질을 검색하는데 많이 이용 되고 있다[2]. ROS (reactive oxygen species)는 체내 방어기전 에 의해 대부분 제거되지만 제거되지 못할 경우 생체분자들과 신속하게 반응하여 단백질의 변성이나 생체막의 지질 과산화,

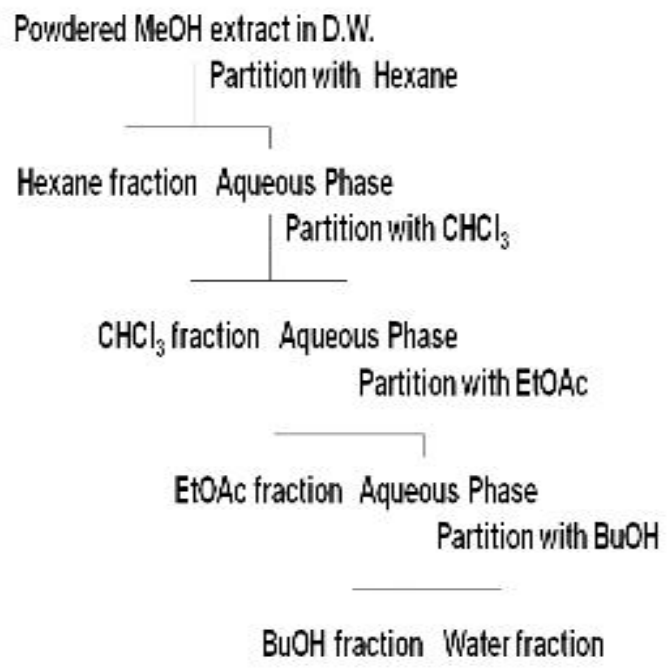

Fig. 1. Fractionation procedure of methanol extract from Rosmarinus officinalis L. by solvent separation. 
DNA 손상 등을 일으키며, 세포 내로 확산되거나 혈류를 통해 이동된 지질 과산화물은 새로운 radical 반응을 촉진시켜 각종 질환의 원인으로 작용 한다[38]. 로즈마리 methanol 추출물 및 분획물의 DPPH free radical 소거활성을 합성 항산화제인 $\mathrm{BHA}$ 와 비교한 결과를 Table 1에 나타내었다. 로즈마리 methanol 추출물은 $10 \mu \mathrm{g} / \mathrm{ml}$ 의 농도에서 $94.35 \%$ 의 DPPH radical 소거 활성을 보였고 $\mathrm{RC}_{50}$ 값은 $5.05 \mu \mathrm{g} / \mathrm{ml}$ 을 보여 매우 높은 $\mathrm{DPPH}$ radical 소거 활성을 가지는 것으로 나타났다. Water 분획물을 제외한 모든 분획물에서 $\mathrm{RC}_{50}$ 값이 $3.22 \sim 6.28 \mathrm{\mu g} / \mathrm{ml}$

Table 1. Scavenging effects of butylated hydroxyanisole (BHA), ascorbic acid and methanol extracts form Rosmarinus Officinalis L., rosmarinic acid, canosic acid on a,a-diphenyl- $\beta$-picrylhydrazyl radical (DPPH)

\begin{tabular}{|c|c|c|c|}
\hline Fractions & Concentration $^{\mathrm{a}}$ & $\begin{array}{c}\text { Scavenging } \\
\text { effect } \% \text { ) }\end{array}$ & $\mathrm{RC}_{50}^{\mathrm{b}}$ \\
\hline & 1 & $13.83 \pm 0.95^{\mathrm{c}}$ & \\
\hline \multirow{3}{*}{ Methanol } & 10 & $94.35 \pm 0.47$ & $5.05 \pm 0.078$ \\
\hline & 100 & $95.81 \pm 0.16$ & \\
\hline & 1 & $12.43 \pm 1.77$ & \\
\hline \multirow[t]{3}{*}{ Hexane } & 10 & $77.11 \pm 8.81$ & $6.28 \pm 0.62$ \\
\hline & 100 & $93.89 \pm 1.03$ & \\
\hline & 1 & $10.79 \pm 2.32$ & \\
\hline \multirow[t]{3}{*}{ Chloroform } & 10 & $93.71 \pm 1.38$ & $5.32 \pm 0.16$ \\
\hline & 100 & $95.46 \pm 0.37$ & \\
\hline & 1 & $35.27 \pm 1.26$ & \\
\hline \multirow[t]{3}{*}{ Ethyl Acetate } & 10 & $95.005 \pm 0.23$ & $3.22 \pm 0.16$ \\
\hline & 100 & $95.64 \pm 0.62$ & \\
\hline & 1 & $15.16 \pm 1.40$ & \\
\hline \multirow[t]{3}{*}{ Buthanol } & 10 & $90.99 \pm 0.49$ & $5.74 \pm 0.93$ \\
\hline & 100 & $94.35 \pm 2.04$ & \\
\hline & 1 & $5.63 \pm 0.05$ & \\
\hline \multirow[t]{3}{*}{ Water } & 10 & $14.10 \pm 0.60$ & $52.28 \pm 0.14$ \\
\hline & 100 & $90.91 \pm 0.14$ & \\
\hline & 1 & $20.7 \pm 4.24$ & \\
\hline \multirow[t]{3}{*}{ Rosmarinic acid } & 10 & $95.45 \pm 0.07$ & $4.52 \pm 0.30$ \\
\hline & 100 & $96.43 \pm 0.16$ & \\
\hline & 1 & $1.32 \pm 1.77$ & \\
\hline \multirow[t]{3}{*}{ Carnosic acid } & 10 & $31.17 \pm 6.29$ & $46.07 \pm 1.84$ \\
\hline & 100 & $94.56 \pm 0.48$ & \\
\hline & 1 & $6.25 \pm 1.89$ & \\
\hline \multirow{3}{*}{ BHA } & 10 & $42.53 \pm 2.78$ & $13.23 \pm 0.76$ \\
\hline & 20 & $71.68 \pm 4.03$ & \\
\hline & 1 & $4.41 \pm 1.78$ & \\
\hline \multirow[t]{2}{*}{ Ascorbic acid } & 10 & $90.24 \pm 7.81$ & $7.47 \pm 0.30$ \\
\hline & 20 & $96.4 \pm 0.06$ & \\
\hline
\end{tabular}

${ }^{a}$ The concentration unit of methanol extract and their fractions was $\mu \mathrm{g} / \mathrm{ml}$, single compounds (rosmarinic acid, carnosic acid, BHA, ascorbic acid) was $\mu \mathrm{M}$.

${ }^{\mathrm{b} C o n c e n t r a t i o n}$ required for $50 \%$ reduction of $\mathrm{DPPH} \cdot$ at 30 min after starting the reaction.

${ }^{c}$ Each value is mean \pm S.D $(n \geq 3)$.
로 나타나 로즈마리 분획물들은 DPPH 소거활성이 매우 높게 나타났으며, 특히 ethyl acetate 분획물의 $\mathrm{RC}_{50}$ 값이 $3.22 \mathrm{\mu g} / \mathrm{ml}$ 로 나타나 분획물 중 가장 높은 활성을 나타냈다. 로즈마리의 단일물질 중에서는 rosmarinic acid의 $\mathrm{RC}_{50}$ 값이 $4.52 \mu \mathrm{M}$ 로 나 타나 가장 높은 효과를 보였고 carnosic acid는 $46.07 \mu \mathrm{M}$ 이었 으며, rosmarinic acid, carnosic acid를 제외한 나머지 단일물 질에서는 DPPH radical의 소거활성이 나타나지 않았다. $\mathrm{BHA}$ 와 ascorbic acid의 $\mathrm{RC}_{50}$ 값은 각각 $2.38 \mu \mathrm{g} / \mathrm{ml}(13.23 \mu \mathrm{M}), 1.32$ $\mu \mathrm{g} / \mathrm{ml}(7.47 \mu \mathrm{M})$ 로 나타나 분획물의 $\mathrm{RC}_{50}$ 값과 비교했을 때 유사한 경향을 보이므로 water 분획물을 제외한 모든 분획물 의 DPPH free radical 소거활성이 매우 우수함을 알 수 있었 다. Kalidas [20] 등은 simple phenol성 물질 중 rosmarinic acid가 항산화 및 항균활성이 높다고 보고하였으며, 본 실험에 서도 rosmarinic acid의 DPPH 소거활성이 천연항산화제인 ascorbic acid의 활성보다 우수하게 나타나 rosmarinic acid가 $\mathrm{DPPH}$ radical 소거활성에 중요한 인자라 생각된다.

\section{Ferric reducing/antioxidant power (FRAP) 측정}

FRAP 측정법은 항산화력을 측정하는 방법 중 하나로 $\mathrm{DPPH}$ 를 이용한 라디칼 소거능을 측정하는 방법과 달리 철이 온의 환원력에 의한 항산화능을 측정할 수 있는 방법이다. Moon 등[31]은 FRAP 법과 DPPH 법은 높은 상관관계를 나타 낸다고 보고하였다. 로즈마리의 분획물과 단일 성분의 FRAP 측정 결과를 Fig. 2에 나타내었다. 실험 결과 분획물의 대부분 이 ascorbic acid $(2.1 \pm 0.03 \mu \mathrm{M} / \mu \mathrm{M})$ 와 비슷한 효과를 보였고 특히 그중에서 buthanol $(4.8 \pm 0.2 \mu \mathrm{M} / \mathrm{\mu g})$, ethyl acetate $(5.9 \pm 0.3 \mu \mathrm{M} / \mathrm{\mu g})$ 의 분획물에서 ascorbic acid 보다 2 배 이상의 높은 효과를 보이는 것을 알 수 있었다. 로즈마리의 단일 성분 에서는 carnosic acid $(0.6 \pm 0.2 \mu \mathrm{M} / \mathrm{\mu M})$ 가 낮은 효과를 보였지 만 rosmarinic acid $(5.1 \pm 0.1 \mu \mathrm{M} / \mathrm{\mu M})$ 는 ascorbic acid 보다 2배 이상의 높은 효과를 보였다.

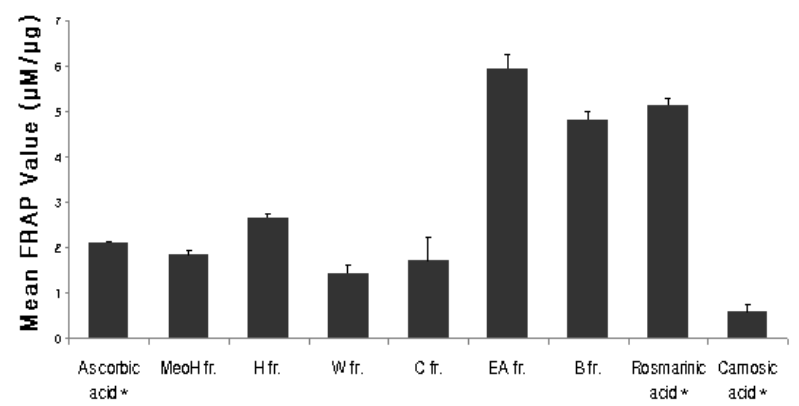

Fig. 2. Total Antioxidant activity of methanol extracts form Rosmarinus Officinalis L., rosmarinic acid, carnosic acid on ferric reducing/antioxidant power (FRAP) activity. FRAP value is expressed as $\mathrm{Fe}^{2+} \mu \mathrm{M}$ concentration, $\mathrm{ob}^{-}$ tained from a $\mathrm{FeSO}_{4}$ solution having an antioxdant $\mathrm{ca}^{-}$ pacity equivalent to that of the dilution of the Rosmarinus Officinalis L. * Mean FRAP value $(\mu \mathrm{M} / \mu \mathrm{M})$. 
이러한 결과는 로즈마리 분획물의 경우 강력한 항산화능을 갖는 phenol류 화합물이 다량으로 포함되어 있기 때문이라고 사료된다. Osawa [33]의 보고에 의하면 식물로부터 추출된 phenol류의 화합물은 항산화능을 포함한 다양한 생물학적 효 능을 나타낸다고 보고하였으며, 이들 효능은 주로 산화환원력 에 의한 것이라고 보고하였다. 또한 Holasova 등[17]은 phenolic compound의 함량이 높을수록 항산화력이 증가한다고 보고 하였다. 따라서 본 실험에서도 로즈마리의 분획물의 환 원력이 증가한 것은 로즈마리에 함유되어 있는 phenol류 화합 물에 의한 것이라 사료되며 Park [34]의 보고에 의하면 가장 항산화성이 높은 로즈마리의 항산화 성분은 rosmarinic acid 가 주를 이룬다는 것으로 본 실험 결과와 일치하였다.

\section{ABTS free radical 소거활성}

ABTS와 potassium persulfate를 암소에 방치하면 ABTS radical (ABTS+·)이 생성되는데 추출물의 항산화력에 의해 $\mathrm{ABTS}+\cdot$ 이 소거되어 radical 특유의 색인 청록색이 탈색된다. 이와 같이 $\mathrm{ABTS}+$ 탈색반응은 이미 생성된 free radical의 제거 정도를 흡광도로 나타내어 $\mathrm{ABTS}+$ 의 소거 활성능을 측정하는 방법으로 $\mathrm{ABTS}+$ 탈색 반응이 1 분 안에 종료 되므 로 단시간에 측정할 수 있고, 소수성과 친수성 모두에 적용 가능하다[26].

본 실험에서는 로즈마리 추출물, 분획물, 단일물질 및 Trolox의 ABTS+· 의 소거활성을 측정하여 Table 2에 나타내 었다. 로즈마리 methanol 추출물은 $100 \mu \mathrm{g} / \mathrm{ml}$ 의 농도에서 $93.05 \%$ 의 높은 $\mathrm{ABTS}+\cdot$ 소거 활성을 보였고, $\mathrm{RC}_{50}$ 값은 8.72 $\mathrm{\mu g} / \mathrm{ml}$ 이었다. 분획물들 중 ethyl acetate층에서 $\mathrm{RC}_{50}$ 값이 5.05 $\mathrm{\mu g} / \mathrm{ml}$ 로 가장 높은 활성을 나타낸 반면에 다른 분획물들의 $\mathrm{RC}_{50}$ 값은 $29.35 \sim 49.55 \mu \mathrm{g} / \mathrm{ml}$ 로 상대적으로 낮은 $\mathrm{ABTS}+\cdot$ 소 거활성을 보였다. $\mathrm{Trolox}$ 의 $\mathrm{RC}_{50}$ 값을 분자량으로 환산하면 $7.34 \mu \mathrm{g} / \mathrm{ml}$ 으로 methanol 추출물 및 ethyl acetate 분획물이 매우 높은 $\mathrm{ABTS}+\cdot$ 소거 활성을 가진다는 것을 알 수 있었으 며, ethyl acetate 분획물은 positive control로 사용된 trolox보 다 ABTS+· 소거 활성이 높게 나타났다. 단일물질 중에서는 rosmarinic acid의 $\mathrm{RC}_{50}$ 값이 $43.16 \mu \mathrm{M}$ 로 나타나 가장 높은 $\mathrm{ABTS}+\cdot$ 소거활성을 보였으며, 이 값은 분자량으로 환산하면 $15.5 \mu \mathrm{g} / \mathrm{ml}$ 로 methanol 추출물이나 ethyl acetate 분획물에 비해 $\mathrm{ABTS}+$ - 소거 활성이 떨어지는 것으로 나타났다. 이 결 과는 로즈마리 추출물의 항산화력이 단일성분 뿐 아니라 여러 가지 성분의 혼합으로 인한 상승작용 때문인 것으로 생각된 다. 또한 DPPH radical 저해 활성이 ABTS radical 저해 활성보 다 높게 나온 경향을 볼 수 있는데 이는 ABTS radical이 DPPH radical보다 좀 더 강력한 산화물질이기 때문인 것으로 사료된 다[9]. 항산화 활성은 methanol 추출물과 ethyl acetate 분획물 에서 가장 활성이 높게 나타났으며 이는 ethyl acetate 분획물 에 함유된 여러 가지 색소류와 페놀류[44]에 의한 것으로 사료
Table 2. Scavenging effects of Trolox and methanol extracts from Rosmarinus Officinalis L., rosmarinic acid on 2,2'-azino-bis (3-ethylbenzthiazoline-6-sulfonic acid) radical (ABTS + )

\begin{tabular}{|c|c|c|c|}
\hline Fractions & Concentration $^{1)}$ & Scavenging effect $(\%)$ & $\mathrm{RC}_{50}{ }^{2)}$ \\
\hline & 1 & $8.85 \pm 0.19^{3)}$ & \\
\hline \multirow[t]{3}{*}{ Methanol } & 10 & $56.93 \pm 3.24$ & $8.72 \pm 0.51$ \\
\hline & 100 & $93.05 \pm 0.03$ & \\
\hline & 1 & $7.89 \pm 0.95$ & \\
\hline \multirow[t]{3}{*}{ Hexane } & 10 & $36.78 \pm 0.67$ & $30.96 \pm 0.27$ \\
\hline & 100 & $93.52 \pm 1.47$ & \\
\hline & 1 & $5.13 \pm 0.17$ & \\
\hline \multirow[t]{2}{*}{ Chloroform } & 10 & $38.33 \pm 2.48$ & $29.35 \pm 3.24$ \\
\hline & 100 & $92.39 \pm 1.47$ & \\
\hline \multirow{3}{*}{$\begin{array}{l}\text { Ethyl } \\
\text { Acetate }\end{array}$} & 1 & $15.47 \pm 4.78$ & \\
\hline & 10 & $92.05 \pm 1.62$ & $5.05 \pm 0.39$ \\
\hline & 100 & $92.78 \pm 0.22$ & \\
\hline \multirow{3}{*}{ Buthanol } & 1 & $8.98 \pm 3.01$ & \\
\hline & 10 & $53.00 \pm 0.52$ & $48.79 \pm 1.96$ \\
\hline & 100 & $92.93 \pm 0.49$ & \\
\hline \multirow{3}{*}{ Water } & 1 & $7.36 \pm 1.45$ & \\
\hline & 10 & $17.24 \pm 2.90$ & $49.55 \pm 0.50$ \\
\hline & 100 & $93.18 \pm 0.01$ & \\
\hline \multirow{3}{*}{$\begin{array}{l}\text { Rosmarinic } \\
\text { acid }\end{array}$} & 1 & $4.28 \pm 1.00$ & \\
\hline & 10 & $35.44 \pm 5.37$ & $43.16 \pm 2.36$ \\
\hline & 100 & 95.15 & \\
\hline \multirow{4}{*}{ Trolox } & 5 & $11.64 \pm 1.10$ & \multirow{4}{*}{$27.16 \pm 1.68$} \\
\hline & 15 & $32.96 \pm 2.46$ & \\
\hline & 30 & $63.14 \pm 5.20$ & \\
\hline & 60 & $94.38 \pm 1.22$ & \\
\hline
\end{tabular}

${ }^{1)}$ The concentration unit of methanol extract and their fractions was $\mu \mathrm{g} / \mathrm{ml}$, single compounds (rosmarinic acid, trolox) was $\mu \mathrm{M} / \mathrm{ml}$

${ }^{2)}$ Concentration required for $50 \%$ reduction of $\mathrm{ABTS}^{+\cdot}$ at 1 min after starting the reaction

${ }^{3)}$ Each value is mean \pm S.D $(n \geq 3)$.

되며 methanol 추출물의 경우 이런 성분들 상호간의 상승작용 에 의해 높은 항산화 활성을 나타내는 것이라 생각된다.

\section{로즈마리 추출물 및 단일성분의 균 생육억제 효과}

로즈마리 분획물을 이용하여 S. aureus, E. coli에 대한 항균 효과를 검색한 결과는 Table 3 에서 보는 것과 같이 methanol 추출물 $5 \mathrm{mg} / \mathrm{disc}$ 의 농도에서 $S$. aureus에 대해 $15.4 \mathrm{~mm}, E$. coli에 대해 $14.3 \mathrm{~mm}$ 의 inhibition zone을 나타냈다. 또한 hexane 분획물에서는 $2.5 \mathrm{mg} / \mathrm{disc}$ 에서 S. aureus에 대해 $12 \mathrm{~mm}$, E. coli에 대해 $13 \mathrm{~mm}$ 의 inhibition zone을 나타냈으며, 5 $\mathrm{mg} / \mathrm{disc}$ 의 농도에서 $S$. aureus에 대해 $12.7 \mathrm{~mm}$ 의 Inhibition zone을 보였고, ethyl acetate 분획물 $5 \mathrm{mg} / \mathrm{disc}$ 에서 $S$. aureus 에 대해 $13.5 \mathrm{~mm}, 2.5 \mathrm{mg} / \mathrm{disc}$ 에서 E. coli에 대해 $14.3 \mathrm{~mm}$ 의 inhibition zone을 보였다. 또한 chloroform 분획물은 2.5 $\mathrm{mg} / \mathrm{disc}$ 의 농도에서 $S$. aureus에 대해 $15.5 \mathrm{~mm}, 5 \mathrm{mg} / \mathrm{disc}$ 의 
Table 3. Antimicrobial activites of Rosmarinus Officinalis L. fractions against Stapylococcus aureus, Escherichia coll

\begin{tabular}{lccc}
\hline \multicolumn{2}{c}{ Fractions } & \multicolumn{3}{c}{ Inhibition zone diameter $(\mathrm{mm})$} \\
\hline Concentration $(\mathrm{mg} /$ disc $)$ & S. aureus & E. coli \\
\hline \multirow{2}{*}{ Methanol } & 2.5 & $15.3 \pm 1.15^{1)}$ & $14.3 \pm 0.50$ \\
& 5 & $15.4 \pm 1.13$ & $14.3 \pm 0.50$ \\
\hline \multirow{2}{*}{ Hexane } & 2.5 & $12 \pm 1.00$ & $13 \pm 1.41$ \\
& 5 & $12.7 \pm 1.15$ & $13 \pm 0.00$ \\
\hline \multirow{2}{*}{ Chloroform } & 2.5 & $15.5 \pm 1.62$ & $13.7 \pm 0.58$ \\
& 5 & $15.1 \pm 1.57$ & $14.3 \pm 1.53$ \\
\multirow{2}{*}{ Ethyl acetate } & 2.5 & $12 \pm 0.01$ & $14.3 \pm 4.16$ \\
& 5 & $13.5 \pm 0.71$ & $13 \pm 2.83$ \\
\multirow{2}{*}{ Buthanol } & 2.5 & $-{ }^{2)}$ & - \\
\hline \multirow{2}{*}{ Water } & 5 & - & - \\
\hline Rosmarinic acid & 1.8 & $11 \pm 1.22$ & $10 \pm 1.41$ \\
\hline
\end{tabular}

${ }^{1)}$ Paper disc $(8 \mathrm{~mm})$ was included.

${ }^{2)}$ No inhibition

농도에서 E. coli에 대해 $14.3 \mathrm{~mm}$ 를 나타내었으나, buthanol, water 분획물에서는 inhibition zone이 전혀 나타나지 않아 항 균활성이 확인 되지 않았다. 또한 단일물질인 rosmarinic acid 는 S. aureus에 대해 $11 \mathrm{~mm}, E$. coli에 대해 $10 \mathrm{~mm}$ 의 inhibition zone을 형성하여 항균활성을 나타냈지만, 나머지 단일물질들
은 inhibition zone을 형성하지 않아 항균활성이 확인 되지 않 았다. 이 때 대조군으로 사용한 $100 \% \mathrm{DMSO}$ 는 두 가지 균에 대한 항균활성에 아무런 영향을 미치지 않았다(data not shown). 로즈마리의 methanol 추출물과 hexane, ethyl acetate, chloroform 분획물 및 rosmarinic acid에서 $S$. aureus, $E$. coli에 대해서 높은 항균력을 가지는 것으로 나타났으며, 이는 항산화 효과와의 연관성은 없는 것으로 보였다.

\section{최소저해농도 측정(Minimum Inhibitory Concentration)}

로즈마리의 추출물과 분획물을 1 차 항균 검색시험인 disc diffusion method [24]을 통해 확인 한 후, 보다 정확한 항균 활성의 농도를 알아보기 위해 paper disc method에서 우수 한 항균력을 보였던 methanol 추출물과 chloroform 분획물 을 사용하여 E. coli와 S. aureus 각각의 균주에 대한 최소저 해농도(MIC)를 측정한 결과는 Fig. 3,4 에 나타내었다. MIC 측정 결과, S. aureaus 균주와 E. coli 균주 모두에서 methanol 추출물은 $5 \mathrm{mg} / \mathrm{ml}$ 의 $\mathrm{MIC}$ 값을 나타내었고 chloroform 분획물은 $2 \mathrm{mg} / \mathrm{ml}$ 에서 $\mathrm{MIC}$ 값을 나타내어 methanol 추출 물에서 보다 chloroform 분획물에서 더 좋은 활성을 나타내 었다. Cho 등[10]에 의하면 E. coli에 대한 창출과 소목, 하고 초 추출물이 $3.2 \mathrm{mg} / \mathrm{ml}$ 에서 $\mathrm{MIC}$ 값을 나타내었고 희렴 추 출물은 $3.4 \mathrm{mg} / \mathrm{ml}$ 에서 $\mathrm{MIC}$ 값을 나타내어 항균효과가 높은
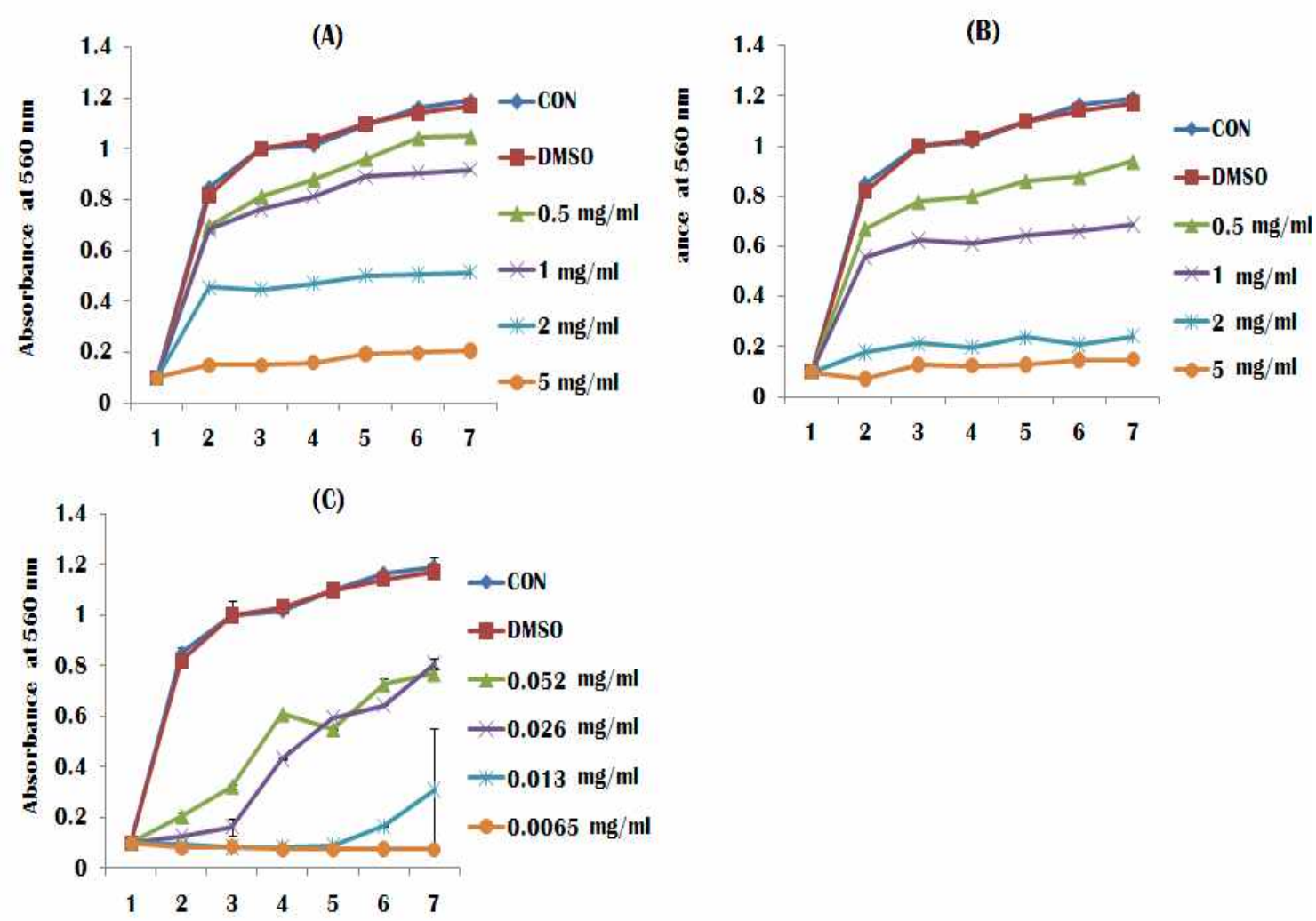

Fig. 3. Effect of the methanol extracts and chloroform fraction from Rosmarinus Officinalis L. and Penicillin on the growth of $S$. aureaus. (A) Methanol extract, (B) Chloroform fraction, (C) Penicillin, CON: Control, DMSO: Dimethyl sulfoxide. 

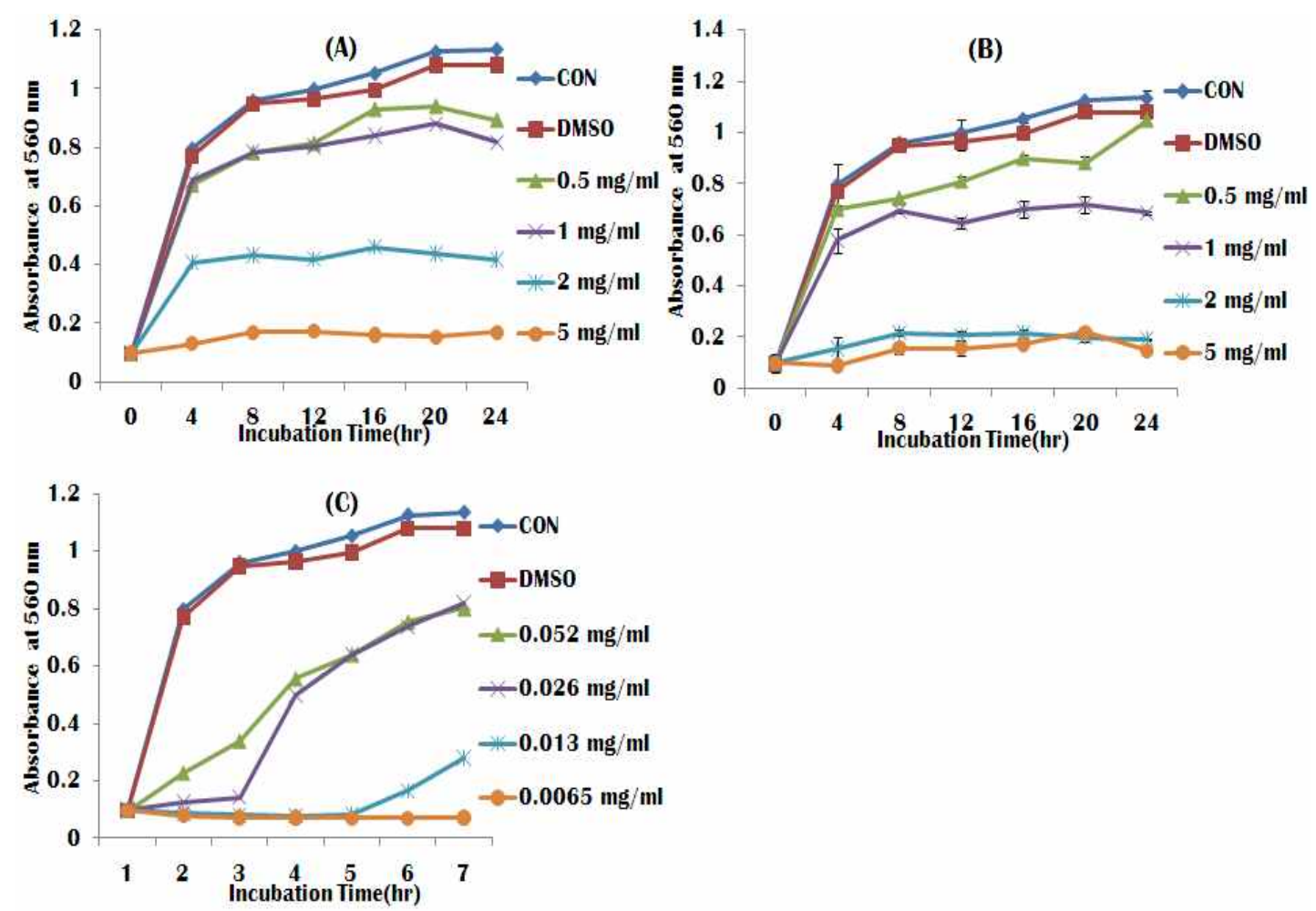

Fig. 4. Effect of the methanol extracts and chloroform fraction from Rosmarinus Officinalis L. and Penicillin on the growth of $E$. coli. (A) Methanol extract, (B) Chloroform fraction, (C) Penicillin, CON: Control, DMSO: Dimethyl sulfoxide.
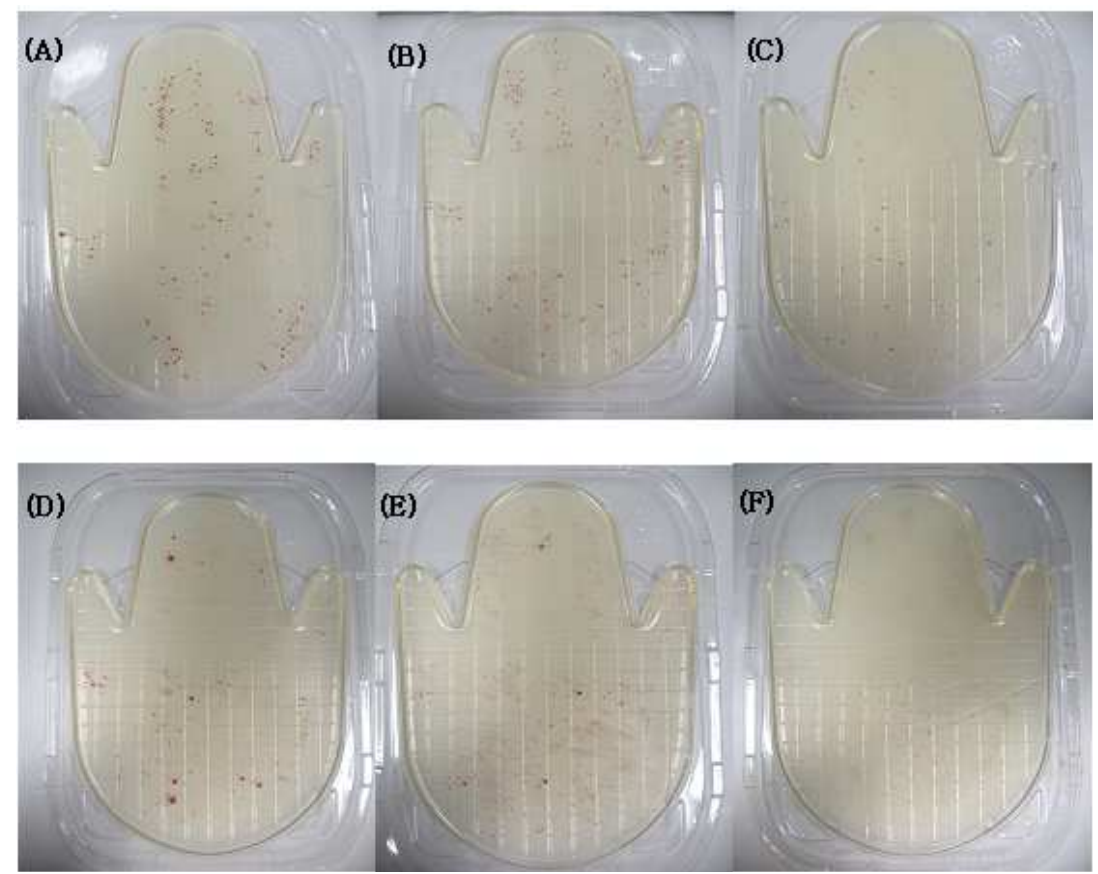

Fig. 5. Antimicrobial activities of Rosmarinus Officinalis L. fractions using hand plate. (A),(D): control (DDW), (B),(E): $1 \%$ methanol extracts, (C),(F): 5\% methanol extracts from Rosmarinus Officinalis L.

것으로 보고되었으며 본 실험의 로즈마리 또한 이와 유사한 $\mathrm{MIC}$ 값을 나타내어 항균효과가 높다고 볼 수 있다. Lee 등
[27]에 의하면 $S$. aureus에 대한 레몬그라스, 꽃잎 ill은 0.625 $\mathrm{mg} / \mathrm{ml}$ 이었고, 로즈마리와 오렌지 oil은 $1.250 \mathrm{mg} / \mathrm{ml}$ 로 $S$. 
aureus 또한 유사한 결과를 나타내었다. 항균활성의 경우 methanol 추출물과 소수성의 hexane, chloroform 분획물에 서 높은 활성을 보였다. 이는 두 소수성 분획물에 함유된 지 질성분과 정유성분에 의한 것[44]으로 사료되며 항균활성 또한 methanol 추출물의 경우 이런 성분들 상호간의 상승 작용에 의한 것으로 생각된다.

\section{로즈마리 메탄올추출물의 손 세정 효과}

로즈마리 추출물의 항균력을 비교적 간편하고 신속하게 효 과를 알 수 있는 hand plate를 이용하여 알아 본 결과는 Fig. 5 와 같다. 실험자 2 인의 손을 이용하여 로즈마리 추출물의 향 균력을 관찰한 결과 두 사람 모두의 결과에서 대조군 (A), (D) 에 비해 $1 \%$ 로즈마리 methanol 추출물 (B), $(\mathrm{E}), 5 \%$ 로즈마리 methanol 추출물 $(\mathrm{C}),(\mathrm{F})$ 에서 각각 농도별로 세균 집락의 색 깔과 수를 감소시킨 것을 알 수 있었다. 이에 Duke [15]의 보고 와 같이 로즈마리가 항균력이 높다는 것을 볼 수 있으며 손 세정제로의 이용가능성을 보여 주었다.

\section{로즈마리 메탄올추출물의 우유 저장성 연장 효과}

Resazurin은 신선유에 대해서는 특유의 청색으로 염색시키 고 점차 환원됨에 따라 청색 $\rightarrow$ 홍자색 $\rightarrow$ 담홍색 $\rightarrow$ 무색으로 변 화하는 색깔에 의해서 Table 4와 비교하여 세균수를 간접적으 로 측정할 수 있다[19]. Resazurin 환원력 실험의 결과 $24 \mathrm{hr}$ 동안 $37^{\circ} \mathrm{C}$ 항온조에 보관한 $\mathrm{B}-1$ 는 홍색을 나타냈고 $72 \mathrm{hr}$ 동안 $37^{\circ} \mathrm{C}$ 항온조에 보관한 B-2는 담홍색을 나타내었으며 약간의 악취를 풍겼다. 냉장 보관하여 청색을 나타낸 A-1과 A-2와 비 교할 때 $24 \mathrm{hr}$ 후인 B-1는 다소 양호한 상태를 유지하고 있었고 $72 \mathrm{hr}$ 후인 B-2는 불량한 상태로 나타났다. $1 \%$ 시료를 처리한 $\mathrm{C}-1, \mathrm{C}-2$ 의 경우 $24 \mathrm{hr}$ 동안 $37^{\circ} \mathrm{C}$ 항온조에 보관하였지만 A-1 과 유사한 청색으로 나타나 상급유를 유지하고 있는 것으로 나타났다. $5 \%$ 시료를 처리한 $\mathrm{D}$ 의 경우 시료 자체의 색이 너무 강해 청색으로의 변화는 나타나지 않았지만 $37^{\circ} \mathrm{C}$ 항온조에 보관한 $\mathrm{B}$ 시료에서 나는 악취는 없었으며 로즈마리향이 강하 게 풍겨 우유의 품질을 효과적으로 보존한 것으로 사료된다. 위의 결과를 통해 항균제와 식품 보존제 등의 상품화는 경제 적이고 그 활성이 우수한 methanol 추출물의 이용이 가장 이 상적인 것으로 판단되어 methanol 추출물을 이용하여 항균제 와 식품 보존제로의 이용가능성을 측정한 결과 항균제로는

Table 4. Standard Color of Resazurin reduction test

\begin{tabular}{|c|c|}
\hline Color & Grade of milk \\
\hline Blue (no color change) & Excellent (Accept) \\
\hline Blue to deep mauve & Good \\
\hline Deep mauve to deep pink & Fair $\}_{\text {Separate }}$ \\
\hline $\begin{array}{l}\text { Deep pink to whitish pink } \\
\text { White }\end{array}$ & $\left.\begin{array}{r}\text { Poor } \\
\text { Bad }\end{array}\right\}_{\text {Reject }}$ \\
\hline
\end{tabular}

\section{(A) Not treated}

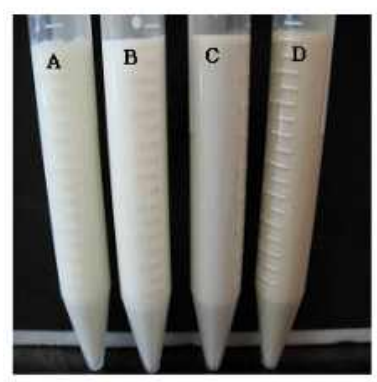

(C) After 72 hours

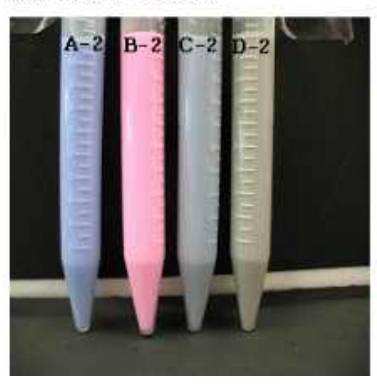

(B) After 24 hours

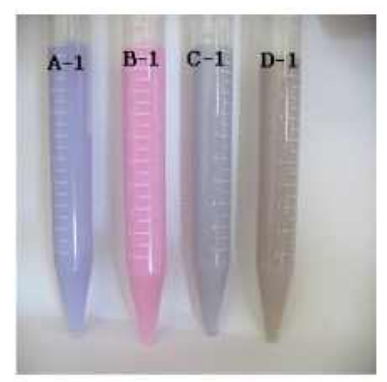

Fig. 6. Evaluation of the storage characteristics of milk added with methanol extracts from Rosmarinus Officinalis L.

hand plate를 통해 $5 \mathrm{mg} / \mathrm{ml}$ 에서 식품 보존제로는 resazurin 환원 실험을 통해 $1 \mathrm{mg} / \mathrm{ml}$ 에서 이용이 가능하리라 생각된다.

\section{감사의 글}

이 논문은 2009년 정부(교육과학기술부)의 재원으로 한국 연구재단[NRF-2009-353-F00018] 및 2010년 교육과학기술부 (지역거점 연구단육성사업/노화극복·웰빙을 위한 융합의료 기술개발사업단)의 지원을 받아 수행되었음에 감사 드립니다.

\section{References}

1. Aligiannis, N., E. Kalpoutzakis, S. Mitaku, and I. B. Chinou. 2001. Composition and antimicrobial activity of the essential oils of two Origanum species. J. Agric. Food Chem. 49, 4168-4179.

2. Al-sereiti, M. R., K. M. Abu-Amer, and P. Sen. 1999. Pharmacology of rosemary (Rosmarinus officinalis Linn) and its therapeutic potentials. Indian J. Exp. Biol. 37, 124-130.

3. Benzie, I. F. F. and J. J. Strain. 1996. The ferric reducing ability of plasma (FRAP) as a measure of "antioxidant power": The FRAP assay. Anal. Biochem. 230, 70-79.

4. Bozin, B., N. Mimica-Dukic. N. Simin, and G. Anackov. 2006. Characterization of the volatile composition of essential oils of some Lamiaceae spices and the antimicirobial and antioxidant activities of the entire oils. J. Agric. Food Chem. 54, 1822-1828.

5. Branen, A. L. 1975. Toxicology and biochemistry of butylated 
hydroxy anisole and butylated hydroxy toluene. J. Am. Oil Chem. Soc. 52, 59-63.

6. Caldefied-Chezet, F., M. Guerry, J. C. Chalchat, C. Fusillier, M. P. Vasson, and J. Guillot. 2004. Anti-inflammatory effects of melaleuca altermifolia essential oil on human polymorphonuclear neutrophils and monocytes. Free Radic. Res. $38,805-811$.

7. Calzada, J., J. F. Ciccio, and G. Echandi. 1980. Antimicrobial activity of the heliangolide chromolaenide and related sesquiterpene lactones. Phytochemistry 19, 967-968.

8. Choi, D. S. and H. Y. Go. 1995. Chemistry of functuonal food. pp. 78-79, JI-GU Publish Co. Seoul.

9. Choi, Y. M., M. H. Kim, J. J. Shin, J. M. Park, J. S. Lee, and M. H. Kim. 2003. The antioxidant activities of the some commercial teas. J. Korean Soc. Food Sci. Nutr. 32, 723-727.

10. Cho, J. Y., I. Choi, and E. K. Hwang. 2003. Antimicrobial activity of extracts from medicinal herbs against Escherichia coli. J. Korean Vet. Res. 43, 625-631.

11. Clark, A. M., F. S. El-Feraly, and W. S. Li. 1981. Antimicrobial activity of phenolic constituents of Magnolia grandiffora L. J. Pharm. Sci. 70, 951-952.

12. Conner, D. E. and L. R. Beuchat. 1984. Effects of essential oils from plants on growth of food spoilage yeasts. J. Food Sci. 49, 429-434.

13. Davidson, P. M. and L. S. Post. 1983. Naturally occurring and miscellaneous food antimicrobials. pp. 371, In Antimicrobials in foods. In Branen, A. L. and P. M. Davidson (eds.), Marcel Dekken Inc., New York.

14. Doldberg, I. 1994. Functional Foods. pp. 3-550, Chapman \& Hall Press. New York.

15. Duke, J. A. 1997. The green pharmacy. pp. 6-23, Rodale Press, New York.

16. Elena, I., C. Alejandro, L. C. Antonio, J. S. Francisco, C. Sofia, and R. Guillenno. 2000. Combined use of supercritical fluid extraction, micellar electrokinetic chromatography, and reverse phase high performance liquid chromatography for the analysis of antioxidants from rosemary (Rosmarinus officinalis). J. Agric. Food Chem. 48, 4060-4065.

17. Holasova, M., V. Fiedlerova, H. Smrcinova, M. Orsak, J. Lachman, and S. Vavreinova. 2002. Buckwheat the source of antioxidant activity in functional foods. Food Res. Int. 35, 207-211.

18. Ito, N., S. Fukushima, A. Hasegawa, M. Shibata, and T. Ogiso. 1983. Carcinogenecity of butylated hydroxy anisole in F344 rats. J. Cancer Inst. 70, 343-347.

19. Jang, H. G., H. O. Kim, M. G. Han, and S. D. Lee. 1991. Food hygiene and experiments. pp. 357-378, Seoul.

20. Kalidas, S. 2001. Biosynthesis and medical application of rosmarinic acid. J. Herbs Spices Med. Plant 8, 161-181.

21. Kim, S. H., M. J. Chung, H. D. Jang, and S. S. Ham. 2010. Antioxidative activities of the Codonopsis lanceolata extract in vitro and in vivo. J. Korean Soc. Food Sci. Nutr. 39, 193-202.

22. Kim, T. S., S. J. Kang, and W. C. Park. 1999. Changes in antioxdants and antioxdants enzymes activities of soybean leaves subject to water stress. J. Korean Soc. Agric. Chem. Biol 42, 246-251.
23. Lewis, R. J. 1989. There regulatory status their use by the food industry. pp. 3-27, In Food additives handbook. In Robert, W. D. (ed.), Nostrand Reinhold. New York.

24. Lee, H. and Y. O. You. 2004. Inhibitory effect of Caeaslpinia sappan on caries inducing properties of Streptococcus mutans and isolation of antibacterial component, brazilin. Wonkwang Univ. Dent. 13, 63-68.

25. Lee, M. K., H. A. Kwon, D. Y. Kwon, H. Park, D. H. Sohn, Y. C. Kim, S. K. Eo, H. Y. Kang, S. W. Kim, and J. H. Lee 2006. Antibacterial activity of medicinal herb extract against Salmonella. Int. J. Food Microbiol. 111, 270-275.

26. Lee, S. O., H. J. Lee, M. H. Yu, H. G. Im, and I. S. Lee. 2005. Total polyphenol contents and antioxidant activities of methanol extract from vegetable produced in Ullung Iand. J. Korean Food Sci. Technol. 37, 233-240.

27. Lee, S. Y., J. G. Kim, B. J. Baik, Y. M. Yang, K. Y. Lee, Y. H. Lee, and M. A. Kim. 2009. Antimicrobial effect of essential oils on oral bacteria. J. Korean Acad. Pediatr. Dent. 36, $1-11$.

28. Mann, C. M. and J. L. Markham. 1998. A new method for determining the minimum inhibitory concentration of essential oils. J. Appl. Microbiol. 84, 538-544.

29. Medeiros, R., G. F. Passos, C. E. Vitor, J. Koepp, T. L Mazzuco, L. F. Pianowski, M. M. Campos, and J. B. Calixto. 2007. Effect of two active compounds obtained from the essential oil of Cordia verbenacea on the acute inflammatory responses elicited by LPS in the rat paw. Br. J. Pharmacol. 151, 618-627.

30. Misaghi, A. and A. A. Basti. 2007. Effects of Zataria Multiflora boiss. essential oil and nisin on Bacillus cereus ATCC 11778. Food Control 18, 1043-1049.

31. Moon, G. S., B. M. Ryu, and M. J. Lee. 2003. Components and antioxidative activities of buchu (Chinese chives) harvested at different times. Korean J. Food Sci. Technol. 35, 493-498.

32. Oh, D. H., S. S. Ham, B. K. Park. C. Ahn, and J. Y. Yu. 1998. Antimicrobial of natural medicinal herbs on the food microorganisms. J. Korean Food Sci. Technol. 30, 957-963.

33. Osawa, T. 1994. Novel natural antioxidant for utilization in food and biological system. pp. 241-251, In Postharvest Biochemistry of Plant Food Material in the Tropics.In Uritani I, V. V. Garcia, E. M. Mendoza (eds.), Japan Scientific Societies Press, Tokyo.

34. Park, G. U. 2002. Healthy function and research situation of herbs in Korea. Alric. Tals. 2, 27-32.

35. Pesch, K. L. and U. Simmert. 1929. Milchw. Forsch. 8, 551.

36. Picman, A. K. and G. H. N. Towers. 1983. Antibacterial activity of sesquiterpene lactones. Biochem. Syst. Ecol. 11, 321-327.

37. Sadaki, O. 1996. The development of functional foods and materials. Bioindustry 13, 44-50.

38. Slater, T. F. 1984. Free-radical mechanisms in tissue injury. Biochem. J. 222, 1-5.

39. Sylvestre, M., A. Pichette, A. Longtin, F. Nagau, and J. Legault. 2006. Essential oil analysis and anticancer activity of leaf essential oil of Croton Flavens L. Form Guadeloupe. J. Ethnopharmacol. 103, 99-102. 
40. Tabanca, N., N. Kirimer, B. Demirci, F. Demirci, and K. H. C. Baser. 2001. Composition and antimicrobial activity of the essential oils of Micromeria cristata subsp. phrygia and the enantiomeric distribution of borneol. J. Agric. Food Chem. 49, 4300-4303.

41. Valko, M., D. Leibfritz, J. Moncol, M. T. Cronin, M. Mazur, and J. Telser. 2007. Free radical and antioxdants in normal physiological function and human disease. Int. J. Biochem. Cell Biol. 39, 44-84.

42. VanBeek, T. A., R. Verpoorte, A. B. Svendsen, and R. Fokkens. 1985. Antimicrobially active alkaloids from
Tabernaemontana chippii. J. Nat. Prod. 48, 400-423.

43. Villar, A., M. Mares, J. L. Rios, E. Canton, and M. Gobernado. 1987. Antimicrobial activity of benzylisoquinoline alkaloids. Pharmazie 42, 248-250.

44. Wo, W. S. 1995. Research Techniques in natural products chemistry. pp. 10-29, Seoul.

45. Yoo, M. J., Y. S. Kim, and D. H. Shin. 2006. Antibacterial effects of natural essential oils from various spices against Vibrio species and their volatile constituents. J. Korean Food Sci. Technol. 38, 438-443.

\section{초록 : 로즈마리 추출물 및 분획물의 항균·항산화 활성}

\section{유미희 ${ }^{1} \cdot$ 채인경 $^{1} \cdot$ 정영태 ${ }^{1} \cdot$ 정연섭 ${ }^{1} \cdot$ 김혁일 ${ }^{1} \cdot$ 이인선 $^{1,2}{ }^{2}$}

( ${ }^{1}$ 계명대학교 식품가공학 전공, ${ }^{2}$ 계명대학교 전통미생물자원개발 및 산업화연구(TMR)센터)

허브류의 하나인 로즈마리를 추출, 분획하여 각 용매별 항산화와 항균효과를 관찰하였다. 로즈마리의 항산화 효과를 측정하기 위해 DPPH radical 소거능과, ABTS radical 소거능 및 FRAP 활성을 측정하였다. DPPH radical 소거능을 측정한 결과 ethyl acetate분획물의 $\mathrm{RC}_{50}$ 값이 $3.22 \mathrm{\mu g} / \mathrm{ml}$ 로 강력한 항산화능을 나타냈으며, water 분획 물을 제외한 나머지 분획물(methanol: $5.05 \mu \mathrm{g} / \mathrm{ml}$, hexane: $6.28 \mu \mathrm{g} / \mathrm{ml}$, chlorofrom: $5.32 \mu \mathrm{g} / \mathrm{ml}$, buthanol: 5.74 $\mu \mathrm{g} / \mathrm{ml}$ )에서도 강력한 항산화능을 보였다. FRAP활성 또한 ethyl acetate 분획물이 $5.9 \pm 0.3 \mu \mathrm{M} / \mathrm{\mu g}$ 의 높은 $\mathrm{Fe}^{2+}$ 함 량을 나타났으며 water 분획물을 제외한 나머지 분획물에서 높은 $\mathrm{Fe}^{2+}$ 함량을 나타내어 DPPH radical 소거능과 유사한 경향을 보였다. ABTS radical 소거능은 ethyl acetate분획물의 $\mathrm{RC}_{50}$ 값이 $5.05 \mu \mathrm{g} / \mathrm{ml}$, methanol 추출물의 $\mathrm{RC}_{50}$ 값이 $8.72 \mu \mathrm{g} / \mathrm{ml}$ 으로 강력한 항산화능을 나타냈으며 그 외 나머지 분획물들은 DPPH radical 소거능보다 상 대적으로 낮은 항산화능을 나타냈다. 로즈마리 단일물질로는 rosmarinic acid, carnosic acid가 DPPH radical 소 거능과 $\mathrm{FRAP}$ 활성에 유사한 경향을 보인 반면 $\mathrm{ABTS}$ radical 소거능은 rosmarinic acid만이 $43.16 \mu \mathrm{M}$ 에서 $\mathrm{RC}_{50}$ 값 을 나타내었다. 로즈마리의 항균 활성은 Paper disc method를 이용한 Inhibition zone과 MIC (최소 저해 농도)를 측정하여 항균력을 알아본 후 hand plate와 resazurin 환원 실험을 통해 항균제와 식품 보존제로서의 이용 가능 성을 알아보았다. 항균 활성 검색 결과 methanol 추출물과 chloroform 분획물이 $S$. aureus에 대해서 $2.5 \mathrm{mg} / \mathrm{disc}$ 의 농도에서 inhibition zone이 각각 $15.3 \mathrm{~mm}, 15.5 \mathrm{~mm}$ 로 높게 나타났으며 E. coli에 대해서 $14.3 \mathrm{~mm}, 13.7 \mathrm{~mm}$ 로 나타나 강력한 항균 효과를 나타내었다. MIC는 S. aureaus 균주와 E. coli 균주 모두 methanol 추출물에서 5 $\mathrm{mg} / \mathrm{ml}$ 의 $\mathrm{MIC}$ 값을 나타내었고 chloroform 분획물은 $2 \mathrm{mg} / \mathrm{ml}$ 에서 $\mathrm{MIC}$ 값을 나타내었다. 항균활성의 경우 methanol 추출물과 소수성의 hexane, chloroform 분획물에서 높은 활성을 보였다. 위의 결과를 통해 항균제와 식품 보존제 등의 상품화는 경제적이고 그 활성이 우수한 methanol 추출물의 이용이 가장 이상적인 것으로 판단 되어 methanol 추출물을 이용하여 항균제와 식품 보존제로의 이용 가능성을 측정한 결과 항균제로는 hand plate 를 통해 $5 \mathrm{mg} / \mathrm{ml}$ 에서 식품 보존제로는 resazurin 환원 실험을 통해 $1 \mathrm{mg} / \mathrm{ml}$ 에서 이용이 가능하리라 생각된다. 